OPEN ACCESS

Edited by: Christian Grenz,

UMR 7294 Institut Méditerranéen d'Océanographie (MIO), France

Reviewed by:

Felix de Tombeur,

University of Liège, Belgium

Simon R. Law,

Umeå University, Sweden

${ }^{*}$ Correspondence: Robinson W. Fulweiler

rwf@bu.edu

Specialty section:

This article was submitted to Marine Ecosystem Ecology, a section of the journal Frontiers in Marine Science

Received: 12 January 2021 Accepted: 06 April 2021 Published: 20 May 2021

Citation: Elizondo EB, Carey JC, Al-Haj AN, Lugo AE and Fulweiler RW (2021) High Productivity Makes Mangroves Potentially Important Players in the Tropical Silicon Cycle.

Front. Mar. Sci. 8:652615. doi: 10.3389/fmars.2021.652615

\section{High Productivity Makes Mangroves Potentially Important Players in the Tropical Silicon Cycle}

\author{
Elani B. Elizondo ${ }^{1}$, Joanna C. Carey ${ }^{1,2}$, Alia N. Al-Haj', Ariel E. Lugo ${ }^{3}$ and \\ Robinson W. Fulweiler ${ }^{1,4 *}$
}

${ }^{1}$ Department of Earth and Environment, Boston University, Boston, MA, United States, ${ }^{2}$ Maths and Science Division, Babson College, Wellesley, MA, United States, ${ }^{3}$ International Institute of Tropical Forestry, USDA Forest Service, Río Piedras, PR, United States, ${ }^{4}$ Department of Biology, Boston University, Boston, MA, United States

Over the last two decades, recognition of the important role terrestrial plants play in regulating silicon (Si) cycling has emerged. Si improves plant fitness by protecting them from abiotic (e.g., desiccation) and biotic (e.g., fungal attack) stressors. Once incorporated into plant biomass this biogenic Si is more bio-available than the lithogenic material from which it was ultimately derived. Thus plants play a key function in regulating the amount and timing of Si availability in downstream ecosystems. Recent work has highlighted the importance of salt marshes in the temperate Si cycle. However, the role of their tropical counterparts, mangroves, has largely gone unexplored. Here we report foliar concentrations of plant Si (as \%Si by dry weight) for four Caribbean mangrove species: Conocarpus erectus (buttonwood), Laguncularia racemosa (white mangrove), Avicennia germinans (black mangrove), and Rhizophora mangle (red mangrove). Overall, the median $\mathrm{Si}$ concentration was low $(0.07 \%)$ and did not vary among plant part (e.g., foliage, twig, and propagule). There was also little variation in Si among species. Using literature values of aboveground net primary production, and the concentrations reported here, we estimate an aboveground mangrove Si uptake rate of 2-10 kg Si $\mathrm{ha}^{-1}$ year $^{-1}$. These rates are on par with rates reported for temperate and boreal forests as well as low nutrient salt marshes, but lower than estimates for high nutrient salt marshes. Thus, despite the low Si concentrations observed in mangroves, their high productivity appears to make them a hot spot of Si cycling in tropical coastal systems.

Keywords: foliage, terrestrial Si cycle, plants, biogeochemistry, silicon

\section{INTRODUCTION}

Silicon $(\mathrm{Si})$ is the second most abundant element in the Earth's crust, and is released as silicic acid [dissolved silica $(\mathrm{DSi}) ; \mathrm{Si}(\mathrm{OH})_{4}$ ] via weathering. A variety of marine organisms are silicifiers including diatoms, radiolarians, silicoflagellates, select sponges, and even picocyanobacteria (Tréguer and De La Rocha, 2013). Photosynthesizing silicifiers (e.g., diatoms) take up significant amounts of $\mathrm{Si}$ along with nitrogen, phosphorus, and inorganic carbon, tightly coupling these biogeochemical cycles (Tréguer et al., 2021). Diatoms are responsible for $\sim 50 \%$ of oceanic primary productivity (Rousseaux and Gregg, 2013) and are an important source of carbon (C) export to the 
deep ocean (Tréguer et al., 2018). Diatoms also play a key role in coastal productivity and food web structure (Hackney et al., 2002).

Over $80 \%$ of the annual inputs of DSi to the global ocean comes from land (Tréguer and De La Rocha, 2013). While rivers are the primary transport mechanism, the path of DSi from land to sea is not direct (Struyf and Conley, 2012). Over the last two decades a new paradigm has emerged that highlights the importance of Si uptake by terrestrial vegetation, with land plants intercepting $\mathrm{Si}$ as it makes its way along the land-ocean continuum (Conley, 2002; Carey and Fulweiler, 2012). In fact, $\mathrm{Si}$ is rapidly recycled through the terrestrial plant reservoir, and this terrestrial cycle helps regulate the flux of Si from continents (Conley, 2002; Carey and Fulweiler, 2012; Struyf and Conley, 2012). Plants take up DSi from the soil solution and groundwater via their roots and transport it throughout the plant where it is deposited as biogenic silica (BSi; Epstein, 1994; Raven, 2003). BSi mostly accumulates as siliceous bodies known as phytoliths at transpiration termini (Epstein, 1994; Raven, 2003). Plants return this BSi to soils, chiefly as litter fall, where it dissolves seven to 20 times faster than mineral silicates (Fraysse et al., 2009; Cornelis et al., 2011). Thus on biological time scales, terrestrial vegetation plays an important yet not fully understood role in altering $\mathrm{Si}$ cycling within and across ecosystems.

Wetlands are borderland ecosystems-not quite terrestrial, not quite aquatic. Yet, they play an important role in regulating the availability of $\mathrm{Si}$ in downstream ecosystems. All plants contain some $\mathrm{Si}$ in their tissue, with concentrations ranging from < $<.1$ to $10 \%$ by dry weight (Epstein, 1999; Raven, 2003; Hodson et al., 2005). Some plants, like those that characterize wetlands (e.g., grasses and sedges), have particularly high BSi concentrations. Thus wetlands are described as "hot spots" for Si cycling (Struyf and Conley, 2009). Wetland sediments also typically contain elevated amorphous silica (ASi) concentrations (Norris and Hackney, 1999; Struyf et al., 2010), particularly in the top sediment layers (Carey and Fulweiler, 2013). ASi is comprised mostly of the BSi fraction in soils, sourced from both plant BSi and benthic algae growth (Carey and Fulweiler, 2013). ASi is also comprised of the non-mineral pedogenic fraction, such as the Si sorbed to iron and aluminum oxi/hydroxides (Saccone et al., 2007; Cornelis et al., 2011). Substantial research effort has focused on Si cycling in temperate wetland ecosystems, specifically tidal freshwater and saltwater marshes, where large Si reservoirs in sediments, plants, and porewater have been documented (Struyf et al., 2005; Carey and Fulweiler, 2013; Müller, 2013). Tidal exchange connects salt marsh Si reservoirs to adjacent estuarine systems, often supplying substantial quantities of DSi to marine waters (Vieillard et al., 2011; Müller et al., 2013; Carey and Fulweiler, 2014a).

While evidence points to the dynamic and critical role of salt marshes in coastal temperate Si cycling, the role of salt marshes' lower latitude counterpart-mangroves-in tropical coastal $\mathrm{Si}$ cycling remains unknown. We hypothesized that mangroves are significant reservoirs of $\mathrm{Si}$ and that their high productivity could make them an important, yet overlooked, driver of tropical $\mathrm{Si}$ cycling. Here we report concentrations of $\mathrm{Si}$ in the foliar tissue of four common species of Caribbean mangrove (Conocarpus erectus (buttonwood), Laguncularia racemosa (white mangrove), Avicennia germinans (black mangrove), Rhizophora mangle (red mangrove) from four locations. We also report twig and propagule Si concentrations for a sub-set of these species, as well as sediment concentrations for one of the study sites. Finally, we estimate net aboveground $\mathrm{Si}$ accretion in mangroves to determine their potential role as $\mathrm{Si}$ reservoirs in coastal tropical systems. To our knowledge, these are the first estimates of Si accretion rates in mangrove forests.

\section{MATERIALS AND METHODS}

We collected samples from San Salvador Island in the Bahamas, Wee Wee Caye in Belize, the western coast of Florida, and at several locations on the island of Puerto Rico (Figure 1). The mangrove species present at each site varied by location, and thus, we did not collect samples from all species at all locations (Table 1). We were able to obtain foliar samples from Rhizophora mangle from all four locations. Samples were collected between 2010 and 2018 across a total of four sampling events. These samples were collected during other field research, coursework, or vacation and this research was not funded, which constrained our sampling ability. At each site we haphazardly collected 2-4 replicates of mangrove foliage, twig, and/or propagule samples from at least two different trees (in most cases; Table 1). In the field, samples were stored in clean, labeled, plastic bags.

In Puerto Rico, we also obtained sediment samples for ASi concentrations from the edge and interior of an Avicennia germinans basin forest. Specifically, we collected triplicate sediment samples at $0-1$ and $1-2 \mathrm{~cm}$ depths.

Upon return to the laboratory, mangrove samples were rinsed with deionized water, and all samples were oven dried at $60^{\circ} \mathrm{C}$ until a constant dry weight was reached. Dried foliar samples and sediment samples were milled using a Wig-L-Bug and $\sim 30 \mathrm{mg}$ samples were digested using a $1 \% \mathrm{Na}_{2} \mathrm{CO}_{3}$ wet alkaline digestion method (DeMaster, 1981; Conley and Schelske, 2002). Sediment samples were digested for a total of $5 \mathrm{~h}$, and we subsampled at hours 3, 4, and 5 so that we could correct for mineral silicate (DeMaster, 1981; Sauer et al., 2006). Briefly, DSi concentrations are plotted overtime and a linear line is fit to the data. If there is no significant DSi concentration change overtime you take an average of the measured concentrations as the sample ASi value. If, however, the linear fit is significant then you extrapolate the linear part to zero and use the Y-intercept as the sample ASi value (DeMaster, 1981; Conley and Schelske, 2002).

The DSi in the digested samples were then analyzed using the molybdenum blue colorimetric method on a Seal AA3 flow injection analyzer (Strickland and Parsons, 1968) and DSi was then converted to \%Si. Internal and external standards were used to ensure that the Seal AA3's results were within $4 \%$ of expected values. Throughout this manuscript, we report biogenic Si as \% Si by dry weight and thus do not refer to it as biogenic silica, which is really $\% \mathrm{SiO}_{2}$. Similarly note, that $\mathrm{ASi}$ is often reported as $\% \mathrm{SiO}_{2}$ and here we report it as $\% \mathrm{Si}$.

We estimated mangrove $\mathrm{Si}$ accretion rates following the methods used by Conley (2002) and Carey and Fulweiler (2012). 


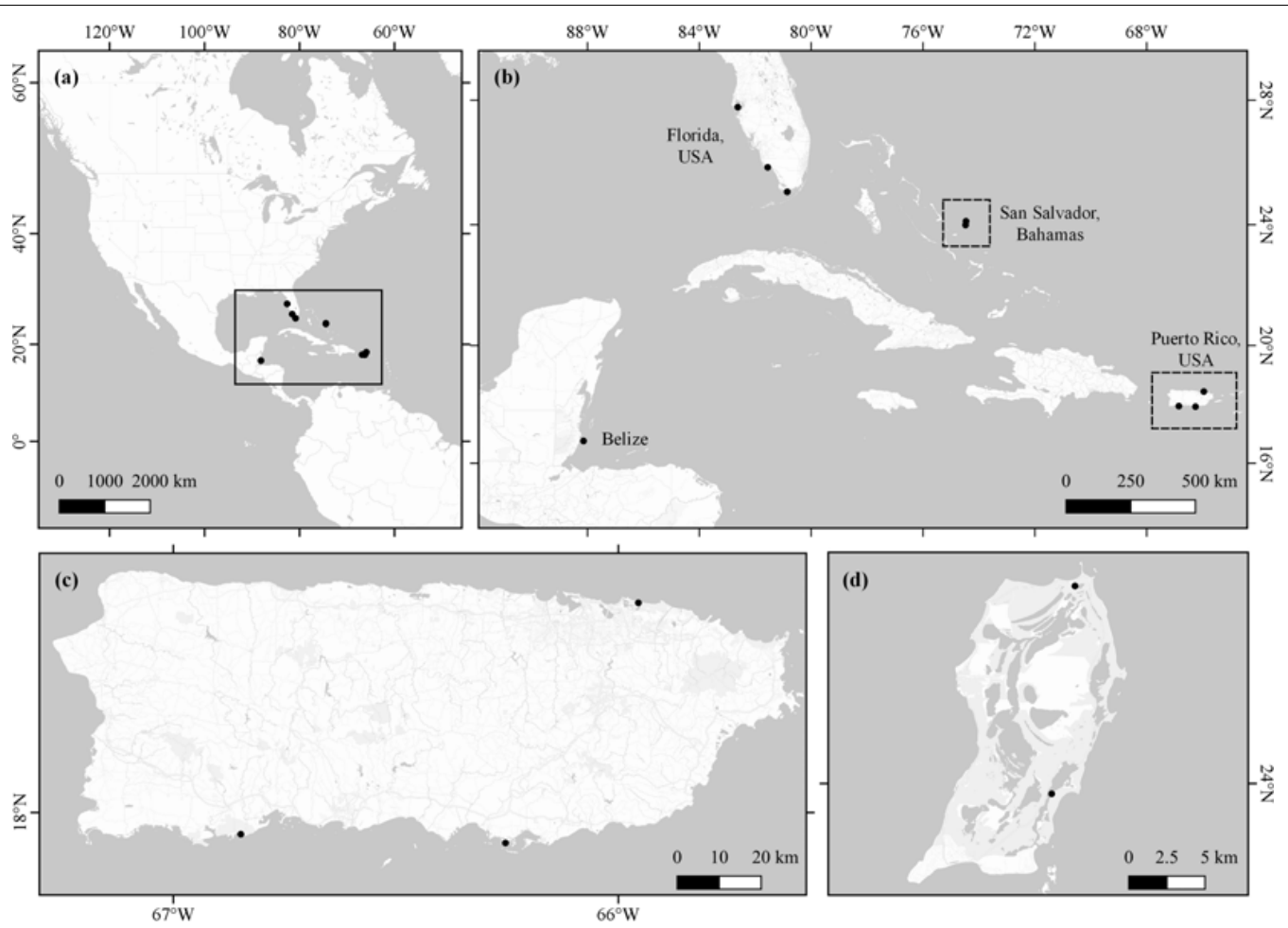

FIGURE 1 | Mangrove samples were collected from Florida and Puerto Rica, USA; San Salvador, Bahamas, and Wee Wee Caye, Belize (a). We collected samples from three sites in Florida (b), three sites in Puerto Rico (c), and two sites in the Bahamas (d).

TABLE 1 | Median, median absolute deviation (mad), sample type, status, and the number of trees sampled ( $n$ ) for mangrove Si concentrations (as \%Si by dry weight) organized by location and species.

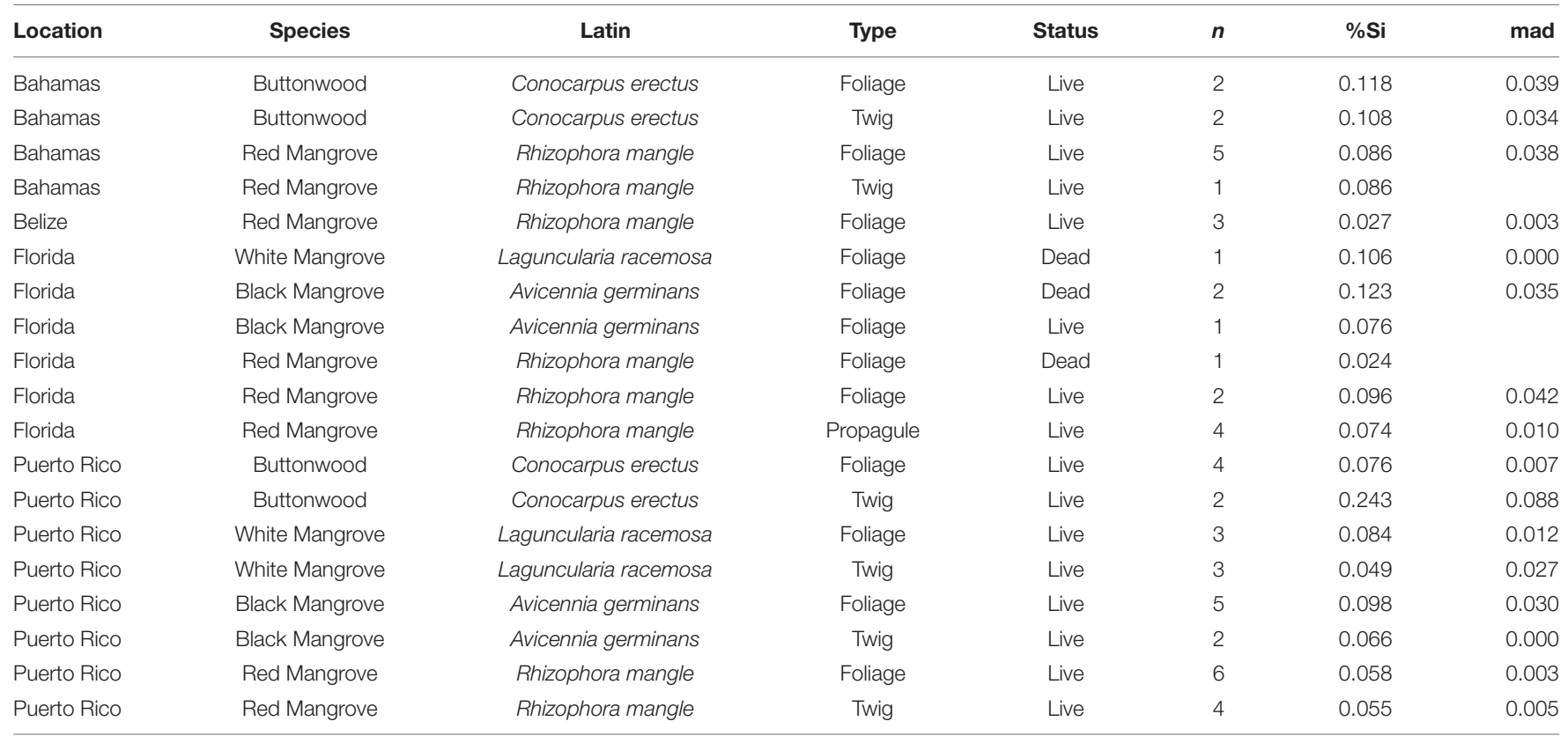

First, we calculated the Si:C ratio by dividing the median mangrove aboveground $\mathrm{Si}$ concentration by $47 \%$, the average $\mathrm{C}$ concentration typically found in mangrove leaves (CastañedaMoya et al., 2013). We then multiplied this Si:C ratio by recently reported estimates of above ground net primary production (NPP) for a representative system: mangroves in Florida (Castañeda-Moya et al., 2013). We report uptake rates in $\mathrm{kg}$ of Si ha ${ }^{-1}$ year $^{-1}$. 
Data analysis was conducted in $\mathrm{R}$ studio version 1.3.1056. We present median \pm median absolute deviation (mad) $\% \mathrm{Si}$ concentrations and used non-parametric statistics (i.e., Kruskal-Wallis test) to compare the \%Si content across the mangrove species and across sites because the data were not normally distributed (Shapiro-Wilk test: $p<0.0001$ ). We considered $p$-value $<0.05$ as significant in this study. The full data set is available at via fighare at: https://figshare.com/s/ 9d49c0f6fe4e63fec7ee

\section{RESULTS}

Plant Si concentrations ranged from $0.02 \%$ in Rhizophora mangle foliage from Florida to $0.24 \%( \pm 0.09)$ in the twigs of Conocarpus erectus from Puerto Rico (Table 1). We observed few significant differences in mangrove $\mathrm{Si}$ concentrations across plant part, location, and species. Including data from all mangrove species, Si concentrations did not differ significantly between plant part sampled (e.g., foliar, twig, or propagule; $p=0.75$ ) or between live or dead samples $(p=0.33)$. In addition to the lack of difference among plant parts or status, we found no significant differences in plant $\mathrm{Si}$ concentrations within a single species by location. For example, Si concentrations in Rhizophora mangle, which was present at all four locations, were the lowest in Belize and the highest in the Bahamas, but not significantly so $(p=0.0686$; Figure 2A).

Within individual species at a single site (i.e., Puerto Rico), we observed little variability in $\mathrm{Si}$ concentrations, with the exception of Avicennia germinans which demonstrated some (Figure 2B). Overall, Rhizophora mangle had the lowest Si concentrations, but only significantly $(p=0.048)$ so when compared Laguncularia racemosa.

In contrast to the low concentrations in the mangrove biomass, we found much higher concentrations of $\mathrm{ASi}$ in sediments from the Avicennia germinans basin forest in Puerto Rico, ranging from 0.42 to $1.94 \% \mathrm{Si}$. ASi concentrations were significantly higher $(p=0.001)$ at the forest edge compared to the interior (median: 0.53 and $1.46 \%$, respectively).

\section{DISCUSSION}

The aboveground mangrove Si concentrations we observed are similar to the those in Rodin and Bazilevich (1967), who report Si concentrations from Rhizophora mucronata leaves $(0.08 \%)$ collected in China as well as Rhizophora mangle leaves $(0.1 \%)$, fruit $(0.11 \%)$, branches $(0.11 \%)$, and sub-aerial roots $(0.24 \%)$ collected in Brazil. Overall, the Si concentrations observed in mangroves are relatively low, especially compared to salt marsh grasses. For example, mature aboveground biomass of Spartina alterniflora, a common salt marsh grass, typically ranges from 0.21 to $0.53 \%$ along its native coast of North America (Norris and Hackney, 1999; Carey and Fulweiler, 2013, 2014b). Similarly, mature aboveground Spartina patens, another native grass commonly found in North American salt marshes, typically exhibit $\mathrm{Si}$ concentrations ranging from
0.14 to $0.42 \%$ (Carey and Fulweiler, 2013, 2014b). Moreover, mature aboveground Juncus Roemerianus, observed in the more southern Mid-Atlantic coast of North America, had higher Si concentrations $(0.0 .21 \%)$ compared to the mangroves we studied here (Norris and Hackney, 1999).

The higher concentrations of $\mathrm{Si}$ observed in salt marsh grasses compared to mangrove trees is not surprising given that grasses are well known to accumulate high concentrations of Si relative to other plant groups (Epstein, 2001; Hodson et al., 2005). Si concentrations in trees vary substantially. For example, Si concentrations in Fagus sylvatica (European beech), Quercus sp. (oak), and Acer sp. (maple) are typically at least an order of magnitude greater $(>0.47 \%$ Si by dry weight) than what we observe in mangrove forests (Cornelis et al., 2010b; Fulweiler et al., 2015; Clymans et al., 2016). Rodin and Bazilevich (1967) report foliar Si concentrations for twenty tropical tree species ranging from $0.03 \%$ for Caparis aphylla to $5.68 \%$ for Lagerstroemia flosreginae. Nevertheless, the low Si concentrations observed in mangrove species are still within the range of observations from other tree species. For example, mangrove foliage Si closely match that of Betula alleghaniensis (yellow birch; $0.16 \pm 0.06 \%$ ) and several temperate gymnosperm tree species, such as Pinus thunbergia (black pine; 0.02-0.05\%) (Cornelis et al., 2010a,b). Moreover, mangrove foliage Si concentrations also nicely align with those of the most common tropical dryland tree species, which typically have Si concentrations $<0.47 \% \mathrm{Si}$ (de Tombeur et al., 2020).

The lower concentrations of $\mathrm{Si}$ in mangroves, compared to higher latitude wetlands and many temperate tree species could be due to several factors. First, DSi availability may be low in Caribbean mangrove systems due to typically low DSi concentrations in tropical marine waters, carbonate platforms, and highly weathered soils (Kaye, 1959; Marfia et al., 2004; Shipe et al., 2006; Gulley et al., 2014; Mattheus and Fowler, 2015). Lower DSi availability in sediments, and therefore sediment porewater, would result in lower $\mathrm{Si}$ accumulation as plants passively (i.e., take up $\mathrm{Si}$ as they take up water) incorporate $\mathrm{Si}$ into their transpiration stream. In addition, soil age may also be a factor dictating Si availability, as Si availability is lowest in young and very old soils and highest in middle-aged sites (de Tombeur et al., 2020). Finally, low Si accumulation in mangrove foliage could be due to relatively low transpiration rates in mangrove ecosystems (Passioura et al., 1992), resulting in less DSi uptake and reduced Si deposition within the plants.

The similar Si concentration we observe across mangrove plant parts (i.e., foliage vs. twig) appears unique among trees. For example, observations from six species of temperate angiosperms and gymnosperms from two separate regions document foliar Si concentrations consistently one or two orders of magnitude greater than woody tissue (Markewitz and Richter, 1998; Cornelis et al., 2010b; Maguire et al., 2017). The lack of difference between foliar and woody tissue in mangroves appears to be a function of their low foliar concentrations, as mangrove low woody $\mathrm{Si}$ concentrations are typical of many tree species.

Sediment ASi concentrations are on par with those reported for temperate forests (Gewirtzman et al., 2019) and several temperate salt marshes, both from North Carolina 


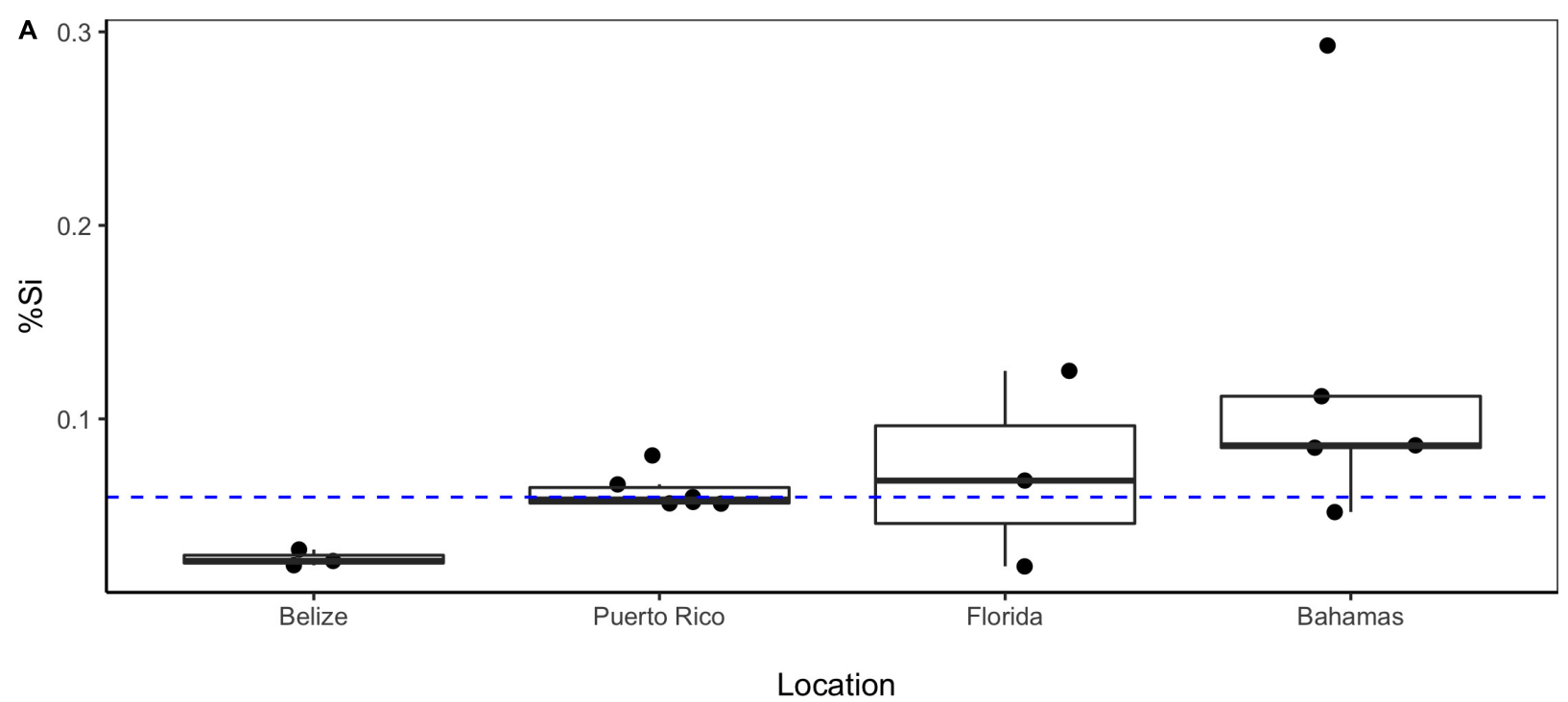

B

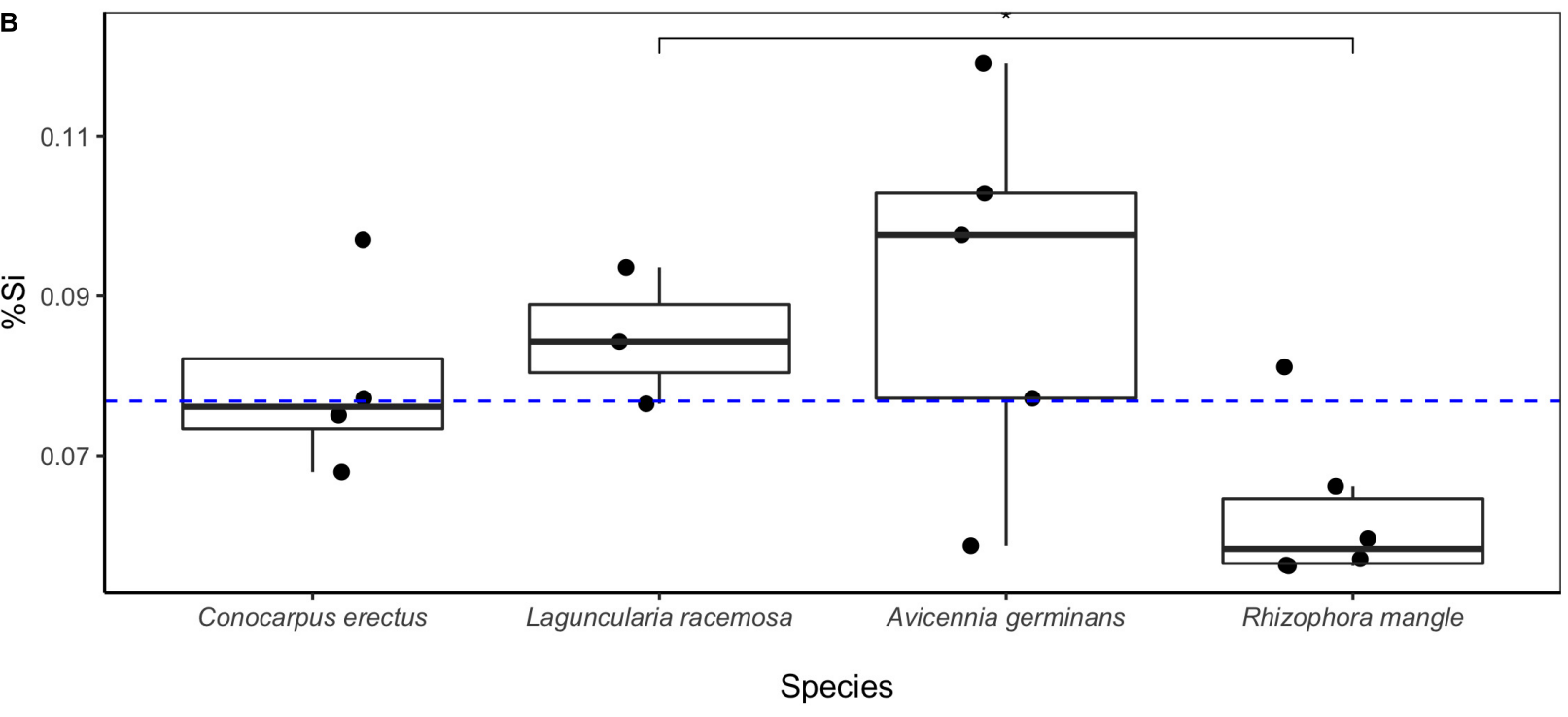

FIGURE 2 | Foliar Si concentrations (as \%Si) of Rhizophora mangle (red mangrove) are not significantly different across the four sampling sites ( $p=0.0686$ ). Median foliar \%Si (dashed blue line) for Rhizophora mangle was 0.06 ( \pm 0.04 median absolute deviation). (A) Foliar Si concentrations (as \%Si) for four mangrove species from Puerto Rico. (B) Laguncularia racemosa Si concentrations are significantly $(p=0.048)$ higher than Si concentrations observed in Rhizophora mangle. Median foliar \%Si (dashed blue line) for mangroves in Puerto Rico was 0.07 ( \pm 0.02$)$. Mangroves are listed in order of the generally observed zonation patterns from inland to coast.

(United States) (Norris and Hackney, 1999) and an outlet of the Yangtze River (China) (Hou et al., 2010). However, the ASi concentrations $(0.42-1.94 \% \mathrm{Si})$ measured in the top $2 \mathrm{~cm}$ of the mangrove sediments we studied here are drastically lower than those reported for the top $1 \mathrm{~cm}$ of sediment in two New England temperate salt marshes ( $\sim 4 \%$ ASi by dry weight) (Carey and Fulweiler, 2013). Clearly, sediment ASi concentrations range dramatically across higher latitude coastal wetlands (i.e., salt marshes) and thus, likely vary across mangrove ecosystems as well. While these data are preliminary, they suggest that mangrove forests may concentrate bio-available Si more in their sediments compared to their biomass. Compared to mineral silicates, ASi is often much more labile, with a large fraction consisting of highly soluble BSi (Saccone et al., 2007; Cornelis et al., 2011). ASi-rich sediment stores could become sources of bioavailable $\mathrm{Si}$ to their surrounding estuaries during periods of erosion and sediment export.

We calculated an aboveground $\mathrm{Si}$ accretion rate by mangroves and, for comparison, salt marshes. Our estimated median aboveground mangrove $\mathrm{Si} \mathrm{C}$ ratio is 0.0015 . Given that foliage and woody tissue $\mathrm{Si}$ concentrations did not significantly vary in the mangroves we study here, we feel comfortable using one value to represent aboveground mangrove $\mathrm{Si} \mathrm{C}$ ratios. Moreover, these ratios are on par with those estimated previously for a range of biomes (Carey and Fulweiler, 2012). We estimate that mangroves 
take up between $\sim 2$ and $10 \mathrm{~kg} \mathrm{Si} \mathrm{ha}^{-1} \mathrm{year}^{-1}$, depending on aboveground productivity at the site. These accretion rates overlap with estimates of aboveground accretion from a low nutrient reference salt marsh dominated by Spartina patens $\left(8 \pm 0.8 \mathrm{~kg} \mathrm{Si} \mathrm{ha}^{-1}\right.$ year $\left.^{-1}\right)$ but are an order of magnitude lower than those observed from a Spartina alterniflora dominated marsh $\left(29 \pm 3.1 \mathrm{~kg} \mathrm{Si} \mathrm{ha}^{-1}\right.$ year $\left.^{-1}\right)$ (Carey and Fulweiler, 2013; Table 2). Moreover mangrove Si uptake is on par with or lower than uptake rates reported for aboveground biomass alone or full ecosystem uptake of $\mathrm{Si}$ in other ecosystems $(2-67 \mathrm{~kg} \mathrm{Si}$ ha $^{-1}$ year $^{-1}$; Table 2).

We recognize that our aboveground mangrove $\mathrm{Si}$ accretion rate values are simplified first estimates that exclude belowground Si accretion, which could be large (Donato et al., 2011; Lamont et al., 2020). It is unclear whether belowground portions of mangroves would exhibit higher or lower $\mathrm{Si}$ concentrations compared to their above counterparts. While similar Si concentrations have been reported for aboveground and belowground biomass of two salt marshes species in an undisturbed system in New England during peak growing season (Carey and Fulweiler, 2013) studies show both similarities and differences between aboveground and belowground $\mathrm{Si}$ concentrations from temperate ecosystems. For example, Gérard et al., 2008 find similar concentrations in fine roots and bole biomass of spruce trees, whereas Maguire et al. (2017) find root $\mathrm{Si}$ concentrations are dramatically higher than aboveground woody tissue but lower than foliage in red maple. Rodin and Bazilevich (1967) reported sub-aerial root Si concentrations that were double that of the foliage and branches in mangroves in Brazil. If such a pattern holds true generally, then mangroves may be sequestering much more Si in their belowground biomass, making their contribution to tropical Si cycling potentially much larger. Clearly, future work should partition aboveground versus belowground mangrove accretion rates, examining how these rates vary spatially and by species.

Compared to higher latitude coastal temperate systems, tropical coastal systems generally exhibit more muted $\mathrm{Si}$

TABLE 2 | Silicon uptake rates ( $\mathrm{kg} \mathrm{Si} \mathrm{ha}^{-1}$ year $^{-1}$ ) as reported for a range of ecosystems and the first estimate for mangroves.

\begin{tabular}{lcc}
\hline Ecosystem type & Silicon uptake rate & References \\
\hline Beech-fir forest* $^{\star}$ & 26 & Bartoli, 1983 \\
Pine forest* $^{\star}$ & 8 & Cornelis et al., 2010b \\
Oak forest & 19 & \\
European beech forest & 24 & \\
Black pine forest & 2 & \\
Douglas fir forest & 31 & \\
Norway spruce forest & 44 & Alexandre et al., 1997 \\
Congo rainforest & 67 & Carey and Fulweiler, 2013 \\
Mixed Deciduous-Conifer forest & 9 & Fulweiler and Nixon, 2005 \\
Mixed Deciduous-Conifer forest & 5 & Garey and Fulweiler, 2013 \\
Douglas fir forest & 44 & This study \\
Temperate salt marsh & $8-29$ & \\
Mangrove forest* & $2-10$ &
\end{tabular}

Note that some estimates (*) are for above ground biomass uptake only. dynamics. For example, unlike coastal temperate waters where diatoms dominate (Rousseau et al., 2002; Barton et al., 2013), the Caribbean phytoplankton community is dominated by coccolithophores (Winter et al., 2002), phytoplankton that do not require Si to survive. While pulses of diatom blooms do occur in the Caribbean (Dandonneau et al., 2006), such blooms are often associated with La Niña events and are short-lived (Alvain et al., 2008). Correspondingly, surface waters of the Caribbean are often Si-depleted, ranging from 2 to $4.5 \mu \mathrm{M}$, depending on the season (Froelich et al., 1978), lower than those typically found in higher latitude coastal systems (Shipe et al., 2006). Together, differences in coastal autotrophic communities, surficial water DSi availability, and coastal wetland type indicates that $\mathrm{Si}$ cycling in tropical systems may be less dynamic compared to higher latitude systems. Mangroves appear to follow this pattern, exhibiting low Si concentrations in their foliage and little differences in Si concentration among aboveground plant parts. However, their elevated primary productivity and standing stock of biomass results in mangrove forests serving as relatively large reservoirs of $\mathrm{Si}$ in tropical coastal systems, reinforcing the idea that wetlands are "hot spots" of Si cycling, even in the tropics. Future research should more robustly account for the differential Si uptake and recycling rates of Si among various plant parts in mangrove systems, as well as the potential for these systems to export $\mathrm{Si}$ to tropical receiving waters via tidal exchange.

\section{DATA AVAILABILITY STATEMENT}

The datasets presented in this study can be found in online repositories. The names of the repository/repositories can be found below: https://figshare.com/s/9d49c0f6fe4e63fec7ee.

\section{AUTHOR CONTRIBUTIONS}

RWF and JCC conceived of this study. AA-H, JCC, AEL, and RWF collected samples. AA-H and JCC processed samples in the laboratory. EBE, JCC, and RWF conducted data analysis and wrote the manuscript. All authors contributed to editing of this manuscript.

\section{FUNDING}

This project was funded in part by a Sloan Foundation Fellowship to RWF. Travel to the Bahamas was funded by the University of Virginia.

\section{ACKNOWLEDGMENTS}

We thank Daniel Orchard, Alexandra Bijak, and Jennie Rheuban for sample collection help in Puerto Rico and in Bahamas. Work in Puerto Rico was done in collaboration with the University of Puerto Rico. We thank Dr. Tim Maguire for helpful discussion on statistics and the role of terrestrial plants in Si cycling. 


\section{REFERENCES}

Alexandre, A., Meunier, J. D., Colin, F., and Koud, J. M. (1997). Plant impact on the biogeochemical cycle of silicon and related weathering processes. Geochim. Cosmochim. Acta 61, 677-682. doi: 10.1016/S0016-7037(97)00001-X

Alvain, S., Moulin, C., Dandonneau, Y., and Loisel, H. (2008). Seasonal distribution and succession of dominant phytoplankton groups in the global ocean: a satellite view. Global Biogeochem. Cycles 22, 1-15. doi: 10.1029/2007GB00 3154

Bartoli, F. J. E. B. (1983). The biogeochemical cycle of silicon in two temperate forest ecosystems. Ecol. Bull. 83, 469-476.

Barton, A. D., Finkel, Z. V., Ward, B. A., Johns, D. G., and Follows, M. J. (2013). On the roles of cell size and trophic strategy in North Atlantic diatom and dinoflagellate communities. Limnol. Oceanogr. 58, 254-266. doi: 10.4319/lo. 2013.58.1.0254

Carey, J. C., and Fulweiler, R. W. (2012). The terrestrial silica pump. PLoS One 7:e52932. doi: 10.1371/journal.pone.0052932

Carey, J. C., and Fulweiler, R. W. (2013). Nitrogen enrichment increases net silica accumulation in a temperate salt marsh. Limnol. Oceanogr. 58, 99-111. doi: 10.4319/lo.2013.58.1.0099

Carey, J. C., and Fulweiler, R. W. (2014a). Salt marsh tidal exchange increases residence time of silica in estuaries. Limnol. Oceanogr. 59, 1203-1212. doi: 10.4319/lo.2014.59.4.1203

Carey, J. C., and Fulweiler, R. W. (2014b). Silica uptake by Spartina-evidence of multiple modes of accumulation from salt marshes around the world. Front. Plant Sci. 5:186. doi: 10.3389/fpls.2014.00186

Castañeda-Moya, E., Twilley, R. R., and Rivera-Monroy, V. H. (2013). Allocation of biomass and net primary productivity of mangrove forests along environmental gradients in the Florida Coastal Everglades, USA. For. Ecol. Manag. 307, 226-241. doi: 10.1016/j.foreco.2013.07.011

Clymans, W., Conley, D. J., Battles, J. J., Frings, P. J., Koppers, M. M., Likens, G. E., et al. (2016). Silica uptake and release in live and decaying biomass in a northern hardwood forest. Ecology 97, 3044-3057. doi: 10.1002/ecy. 1542

Conley, D. J. (2002). Terrestrial ecosystems and the global biogeochemical silica cycle. Global Biogeochem. Cycles 16, 1-8. doi: 10.1029/2002GB001894

Conley, D. J., and Schelske, C. L. (2002). "Biogenic silica," in Tracking Environmental Change Using Lake Sediments, eds J. P. Smol, H. J. B. Birks, W. M. Last, R. S. Bradley, and K. Alverson (Dordrecht: Kluwer Academic Publishers), 281-293. doi: 10.1007/0-306-47668-1_14

Cornelis, J. T., Delvaux, B., and Titeux, H. (2010a). Contrasting silicon uptakes by coniferous trees: a hydroponic experiment on young seedlings. Plant Soil 336, 99-106. doi: 10.1007/s11104-010-0451-x

Cornelis, J. T., Delvaux, B., Georg, R. B., Lucas, Y., Ranger, J., and Opfergelt, S. (2011). Tracing the origin of dissolved silicon transferred from various soilplant systems towards rivers: a review. Biogeosciences 8, 89-112. doi: 10.5194/ bg-8-89-2011

Cornelis, J. T., Ranger, J., Iserentant, A., and Delvaux, B. (2010b). Tree species impact the terrestrial cycle of silicon through various uptakes. Biogeochemistry 97, 231-245. doi: 10.1007/s10533-009-9369-X

Dandonneau, Y., Montel, Y., Blanchot, J., Giraudeau, J., and Neveux, J. (2006). Temporal variability in phytoplankton pigments, picoplankton and coccolithophores along a transect through the North Atlantic and tropical southwestern Pacific. Deep Sea Res. Part I Oceanogr. Res. Pap. 53, 689-712. doi: 10.1016/j.dsr.2006.01.002

de Tombeur, F., Turner, B. L., Laliberte, E., Lambers, H., and Cornelis, J. T. (2020). Silicon dynamics during 2 million years of soil development in a coastal dune chronosequence under a Mediterranean climate. Ecosystems 23, 1614-1630.

de Tombeur, F., Turner, B. L., Laliberté, E., Lambers, H., Mahy, G., Faucon, M.P., et al. (2020). Plants sustain the terrestrial silicon cycle during ecosystem 1 retrogression. Science 369, 1245-1248.

DeMaster, D. J. (1981). The supply and accumulation of silica in the marine environment. Geochim. Cosmochim. Acta 45, 1715-1732. doi: 10.1016/00167037(81)90006-5

Donato, D. C., Kauffman, J. B., Murdiyarso, D., Kurnianto, S., Stidham, M., and Kanninen, M. (2011). Mangroves among the most carbon-rich forests in the tropics. Nat. Geosci. 4, 293-297. doi: 10.1038/ngeo1123
Epstein, E. (1994). The anomaly of silicon in plant biology. Proc. Natl. Acad. Sci. U.S.A. 91, 11-17.

Epstein, E. (1999). Silicon. Annu. Rev. Plant Physiol. Plant Mol. Biol. 50, 641-664. doi: 10.1146/annurev.arplant.50.1.641

Epstein, E. (2001). Silicon in plants: facts vs. concepts. Stud. Plant Sci. 8, 1-15. doi: 10.1016/S0928-3420(01)80005-7

Fraysse, F., Pokrovsky, O. S., Schott, J., and Meunier, J. D. (2009). Surface chemistry and reactivity of plant phytoliths in aqueous solutions. Chem. Geol. 258, 197-206. doi: 10.1016/j.chemgeo.2008.10.003

Froelich, P. N., Atwood, D. K., and Giese, G. S. (1978). Influence of amazon river discharge on surface salinity and dissolved silicate concentration in the Caribbean sea. Deep Sea Res. 25, 735-744. doi: 10.1016/0146-6291(78)90627-6

Fulweiler, R. W., Maguire, T. J., Carey, J. C., and Finzi, A. C. (2015). Does elevated CO alter silica uptake in trees? Front. Plant Sci. 5:793. doi: 10.3389/fpls.2014. 00793

Fulweiler, R. W., and Nixon, S. W. (2005). Terrestrial vegetation and the seasonal cycleof dissolved silica in a southern New Englandcoastal river. Biogeochemistry 74, 115-130. doi: 10.1007/s10533-004-2947-z

Gérard, F., Mayer, K. U., Hodson, M. J., and Ranger, J. (2008). Modelling the biogeochemical cycle of silicon in soils: application to a temperate forest ecosystem. Geochim. Cosmochim. Acta 72, 741-758. doi: 10.1016/j.gca.2007.11. 010

Gewirtzman, J., Tang, J., Melillo, J. M., Werner, W. J., Kurtz, A. C., Fulweiler, R. W., et al. (2019). Soil warming accelerates biogeochemical silica cycling in a temperate forest. Front. Plant Sci. 10:1097. doi: 10.3389/fpls.2019.01097

Gulley, J. D., Martin, J. B., Spellman, P., Moore, P. J., and Screaton, E. J. (2014). Influence of partial confinement and Holocene river formation on groundwater flow and dissolution in the Florida carbonate platform. Hydrol. Process. 28, 705-717. doi: 10.1002/hyp.9601

Hackney, C. T., Cahoon, L. B., Preziosi, C., and Norris, A. (2002). "Silicon is the link between tidal marshes and estuarine fisheries: a new paradigm," in Concepts and Controversies in Tidal Marsh Ecology, eds M. P. Weinstein and D. A. Kreeger (Dordrecht: Springer), 543-552.

Hodson, M. J., White, P. J., Mead, A., and Broadley, M. R. (2005). Phylogenetic variation in the silicon composition of plants. Ann. Bot. 96, 1027-1046. doi: 10.1093/aob/mci255

Hou, L., Liu, M., Yang, Y., Ou, D., Lin, X., and Chen, H. (2010). Biogenic silica in intertidal marsh plants and associated sediments of the Yangtze Estuary. J. Environ. Sci. 22, 374-380. doi: 10.1016/s1001-0742(09)60118-2

Kaye, C. A. (1959). Coastal Geology of Puerto Rico. Washington, DC: United States Government Printing Office, 68.

Lamont, K., Saintilan, N., Kelleway, J. J., Mazumder, D., and Zawadzki, A. (2020). Thirty-year repeat measures of mangrove above- and below-ground biomass reveals unexpectedly high carbon sequestration. Ecosystems 23, 370-382. doi: 10.1007/s10021-019-00408-3

Maguire, T. J., Templer, P. H., Battles, J. J., and Fulweiler, R. W. (2017). Winter climate change and fine root biogenic silica in sugar maple trees (Acer saccharum): implications for silica in the Anthropocene. J. Geophys. Res. Biogeosciences 122, 708-715. doi: 10.1002/2016JG003755

Marfia, A. M., Krishnamurthy, R. V., Atekwana, E. A., and Panton, W. F. (2004). Isotopic and geochemical evolution of ground and surface waters in a karst dominated geological setting: a case study from Belize, Central America. Appl. Geochem. 19, 937-946. doi: 10.1016/j.apgeochem.2003.10.013

Markewitz, D., and Richter, D. D. (1998). The bio in aluminum and silicon geochemistry. Biogeochemistry 42, 235-252.

Mattheus, C. R., and Fowler, J. K. (2015). Paleotempestite distribution across an isolated carbonate platform, San Salvador Island, Bahamas. J. Coast. Res. 31, 842-858. doi: 10.2112/JCOASTRES-D-14-00077.1

Müller, F. (2013). Management Effects on Ecosystem Functions of Salt Marshes: Silica Cycling and Sedimentation Processes. Available online at: http://ediss.sub.unihamburg.de/volltexte/2013/6105/ (accessed September 12, 2017)

Müller, F., Struyf, E., Hartmann, J., Wanner, A., and Jensen, K. (2013). A comprehensive study of silica pools and fluxes in Wadden sea salt marshes. Estuar. Coast. 36, 1150-1164. doi: 10.1007/s12237-013-9621-4

Norris, A. R., and Hackney, C. T. (1999). Silica content of a Mesohaline tidal marsh in North Carolina. Estuar. Coast. Shelf Sci. 49, 597-605. doi: 10.1006/ecss.1999. 0506 
Passioura, J. B., Ball, M. C., and Knight, J. H. (1992). Mangroves may salinize the soil and in so doing limit their transpiration rate. Funct. Ecol. 8, 476-481. doi: $10.2307 / 2389286$

Raven, J. A. (2003). Cycling silicon - the role of accumulation in plants. New Phytol. 158, 419-421. doi: 10.1046/j.1469-8137.2003.00778.x

Rodin, L. E., and Bazilevich, N. I. (1967). Production and Mineral Cycling in Terrestrial Vegetation. London: Oliver \& Boyd.

Rousseau, V., Leynaert, A., Daoud, N., and Lancelot, C. (2002). Diatom succession, silicification and silicic acid availability in Belgian coastal waters (Southern North Sea). Mar. Ecol. Prog. Ser. 236, 61-73. doi: 10.3354/meps236061

Rousseaux, C. S., and Gregg, W. W. (2013). Interannual variation in phytoplankton primary production at a global scale. Remote Sens. 6, 1-19. doi: 10.3390/ rs6010001

Saccone, L., Conley, D. J., Koning, E., Sauer, D., Sommer, M., Kaczorek, D., et al. (2007). Assessing the extraction and quantification of amorphous silica in soils of forest and grassland ecosystems. Eur. J. Soil Sci. 58, 1446-1459. doi: 10.1111/ j.1365-2389.2007.00949.x

Sauer, D., Saccone, L., Conley, D. J., Herrmann, L., and Sommer, M. (2006). Review of methodologies for extracting plant-available and amorphous Si from soils and aquatic sediments. Biogeochemistry 80, 89-108. doi: 10.1007/s10533-0055879-3

Shipe, R. F., Curtaz, J., Subramaniam, A., Carpenter, E. J., and Capone, D. G. (2006). Diatom biomass and productivity in oceanic and plume-influenced waters of the western tropical Atlantic ocean. Deep Sea Res. Part I Oceanogr. Res. Pap. 53, 1320-1334. doi: 10.1016/j.dsr.2006.05.013

Strickland, J., and Parsons, T. (1968). A Practical Handbook of Seawater Analysis, 2nd Edn. Ottawa, ON: Fisheries Research Board of Canada.

Struyf, E., and Conley, D. J. (2009). Silica: an essential nutrient in wetland biogeochemistry. Front. Ecol. Environ. 7:88-94. doi: 10.1890/070126

Struyf, E., and Conley, D. J. (2012). Emerging understanding of the ecosystem silica filter. Biogeochemistry 107, 9-18. doi: 10.1007/s10533-011-9590-2

Struyf, E., Damme, S., Van Gribsholt, B., and Meire, P. (2005). Freshwater marshes as dissolved silica recyclers in an estuarine environment (Schelde estuary, Belgium). Hydrobiologia 540, 69-77. doi: 10.1007/s10750-0047104-0

Struyf, E., Mörth, C.-M., Humborg, C., and Conley, D. J. (2010). An enormous amorphous silica stock in boreal wetlands. J. Geophys. Res. 115:G04008. doi: 10.1029/2010JG001324

Tréguer, P., Bowler, C., Moriceau, B., Dutkiewicz, S., Gehlen, M., Aumont, O., et al. (2018). Influence of diatom diversity on the ocean biological carbon pump. Nat. Geosci. 11, 27-37. doi: 10.1038/s41561-017-0028-x

Tréguer, P. J., and De La Rocha, C. L. (2013). The world ocean silica cycle. Ann. Rev. Mar. Sci. 5, 477-501. doi: 10.1146/annurev-marine-121211-172346

Tréguer, P. J., Sutton, J. N., Brzezinski, M., Charette, M. A., Devries, T., Dutkiewicz, S., et al. (2021). Reviews and syntheses: the biogeochemical cycle of silicon in the modern ocean. Biogeosciences 18, 1269-1289. doi: 10.5194/bg-18-12692021

Vieillard, A. M., Fulweiler, R. W., Hughes, Z. J., and Carey, J. C. (2011). The ebb and flood of Silica: quantifying dissolved and biogenic silica fluxes from a temperate salt marsh. Estuar. Coast. Shelf Sci. 95, 415-423. doi: 10.1016/j.ecss.2011.10. 012

Winter, A., Rost, B., Hilbrecht, H., and Elbrächter, M. (2002). Vertical and horizontal distribution of coccolithophores in the Caribbean Sea. Geo Marine Lett. 22, 150-161. doi: 10.1007/s00367-002-0108-8

Conflict of Interest: The authors declare that the research was conducted in the absence of any commercial or financial relationships that could be construed as a potential conflict of interest.

Copyright (C) 2021 Elizondo, Carey, Al-Haj, Lugo and Fulweiler. This is an openaccess article distributed under the terms of the Creative Commons Attribution License (CC BY). The use, distribution or reproduction in other forums is permitted, provided the original author(s) and the copyright owner(s) are credited and that the original publication in this journal is cited, in accordance with accepted academic practice. No use, distribution or reproduction is permitted which does not comply with these terms. 